\title{
Up-regulation of P-glycoprotein confers acquired resistance to 6-mercaptopurine in human chronic myeloid leukemia cells
}

\author{
XING-XIANG PENG ${ }^{1,5}$, ZHI SHI $^{1,2}$, AMIT K. TIWARI ${ }^{1}$, VIJAYA L. DAMARAJU ${ }^{3}$, LIWU FU ${ }^{2}$, \\ CAROL E. CASS ${ }^{3}$, CHARLES R. ASHBY Jr ${ }^{1}$, GARY D. KRUH ${ }^{4}$ and ZHE-SHENG CHEN ${ }^{1}$
}

\begin{abstract}
${ }^{1}$ Department of Pharmaceutical Sciences, College of Pharmacy and Allied Health Professions, St. John's University, Queens, NY 11439, USA; ${ }^{2}$ State Key Laboratory for Oncology in South China, Cancer Center, Sun Yat-Sen University, Guangzhou, P.R. China; ${ }^{3}$ Department of Oncology, Cross Cancer Institute and University of Alberta, Edmonton, AB, Canada; ${ }^{4}$ UIC Cancer Center, University of Illinois at Chicago College of Medicine, Chicago, IL 60612, USA
\end{abstract}

Received December 7, 2010; Accepted March 11, 2011

DOI: $10.3892 / \mathrm{ol} .2011 .288$

\begin{abstract}
To investigate the mechanisms of cellular resistance to 6-mercaptopurine (6-MP) in chronic myeloid leukemia (CML), a 6-MP resistant cell line (K562-MP5) was established by stepwise selection of the CML cell line (K562). The results of the drug sensitivity analysis of the K562-MP5 cell line revealed the cells to be 339-fold more resistant to 6-MP compared with the parental K562 cells. K562-MP5 cells exhibited decreased accumulation and increased efflux of $\left[{ }^{14} \mathrm{C}\right] 6-\mathrm{MP}$ and its metabolites. In addition, K562-MP5 cells showed increased $\left[{ }^{3} \mathrm{H}\right] \mathrm{MTX}$ transport. K562-MP5 cells over-expressed P-glycoprotein (P-gp) and up-regulated MDR1 mRNA levels. Taken together, these results suggest that the up-regulation
\end{abstract}

Correspondence to: $\mathrm{Dr}$ Zhe-Sheng Chen, Department of Pharmaceutical Sciences, College of Pharmacy and Allied Health Professions, St. John's University, Queens, NY 11439, USA

E-mail: chenz@stjohns.edu

Present address: ${ }^{5}$ Department of Psychiatry and Pharmacology, School of Medicine, New York University, 550 First Av., New York, NY 10016, USA

Abbreviations: ABC, ATP-binding cassette; ALL, acute lymphoblastic leukemia; BCRP/ABCG2, breast cancer resistance protein; $\mathrm{CBB}$, Coomassie brilliant blue; CML, chronic myeloid leukemia; FBS, fetal bovine serum; GAPDH, glyceraldehyde-3-phosphate dehydrogenase; hENT, human equilibrative nucleoside transporter; hCNT, human concentrative nucleoside transporter; HGPRT, hypoxanthine guanine phosphoribosyltransferase; IMPDH, inosine monophosphate dehydrogenase; MDR, multidrug resistance; 6-MMPR, 6-methylmercaptopurine riboside; 2-MP, 2-mercaptopurine; 6-MP, 6-mercaptopurine; MRP, multidrug resistance protein; MTT, 1-(4,5-dimethylthiazol-2-yl)-3,5-diphenylformazan; MTX, methotrexate; MX, mitoxantrone; NT(s), nucleoside transporter(s); PBS, phosphate-buffered saline; P-gp, P-glycoprotein; PMEA, 9-(2-phosphonylmethoxyethyl) adenine; 6-TG, 6-thioguanine; TPMT, thiopurine methyltransferase

Key words: chronic myeloid leukemia, multidrug resistance, 6-mercaptopurine, P-glycoprotein, ATP binding cassette transporter of P-gp, which contributes to the decreased accumulation by increasing the efflux of 6-MP and its metabolites, underlies the mechanism of 6-MP resistance in K562 cells.

\section{Introduction}

The clinical development of resistance to chemotherapeutic drugs is one of the major factors responsible for the failure of cancer chemotherapy. Cancer cells may become resistant to a variety of drugs with different structures or cellular targets, a phenomenon called multidrug resistance (MDR) (1-4). As a nucleobase anti-cancer drug, 6-mercaptopurine (6-MP) is widely used in maintenance therapy for childhood acute lymphoblastic leukemia (ALL) (1,5-7). Recently, we explored the possible mechanisms underlying clinical resistance to 6-MP in ALL, including the up-regulation of ATP-binding cassette (ABC), down-regulation of plasma membrane nucleoside transporters (NTs) and alterations in activities of metabolic enzymes.

P-glycoprotein (P-gp/MDR1) is a member of the ABC superfamily of transmembrane transporters, and it functions as a direct active transporter of a variety of drugs (8). The overexpression of P-gp and MRP1 was shown to correlate with short survival in patients with adult T-cell leukemia $(9,10)$. However, over the last two decades, it has become evident that P-gp is not the only human ABC transporter that, at least in vitro, is able to confer resistance to clinically significant chemotherapeutic agents leading to $\operatorname{MDR}(1,3$, 11-16). In humans, the $\mathrm{ABC}$ transporter superfamily comprises 49 genes that belong to a 'family tree' with 7 designated branches (A to $G)(17,18)$. The human multidrug resistance protein (MRP) family consists of 10 members and MRPs 1-8 have been isolated and proven to be involved in drug resistance (19-21). Extensive studies showed that over-expression of MRP4, MRP5, MPR8 and breast cancer resistance protein (BCRP/ABCG2) confers resistance to nucleobase and nucleoside analogs $(13,14,16,22-27)$. In a recent study, it was observed that over-expressed MRP4 plays a significant role in conferring resistance to 6-MP in ALL by reducing accumulation of $\left[{ }^{14} \mathrm{C}\right] 6-\mathrm{MP}$ and its metabolites in cells by acting as an efflux pump (28). 
Most nucleoside analogs enter cells via the plasma membrane nucleoside transporters; a decrease of nucleoside transporters leads to decreased drug uptake (29-31). Our previous study revealed that down-regulation of human equilibrative nucleoside transporter 1 (hENT1) and human concentrative nucleoside transporters 2 and 3 (hCNT2 and hCNT3), leading to decreased accumulation of 6-MP in cells with acquired resistance to 6-MP, was involved in 6-MP resistance in ALL (28).

As a pro-drug, 6-MP undergoes extensive metabolism inside cells to become active metabolites. The effects of 6-MP are mediated via its intracellular conversion to the 6-thioguanine nucleotides and 6-methyl-thioinosine 5'-monophosphate, which are active metabolites of 6-MP. Thiopurine methyltransferase (TPMT) and hypoxanthine guanine phosphoribosyl transferase (HGPRT) are the two key enzymes responsible for catalyzing these reactions. In the previous study, it was found that the activity of 6-MP metabolic enzyme TPMT was increased in the 6-MP-resistant cells in ALL (28). This study aimed to investigate whether the mechanisms involved in 6-MP-resistant cells apply to chronic myeloid leukemia (CML).

\section{Materials and methods}

Reagents. $\left[{ }^{14} \mathrm{C}\right] 6-\mathrm{MP}(51 \mathrm{mCi} / \mathrm{mmol}),\left[{ }^{14} \mathrm{C}\right]$ inosine monophosphate $(50 \mathrm{mCi} / \mathrm{mmol})$ and $\left[{ }^{14} \mathrm{C}\right]$-hypoxanthine $(47 \mathrm{mCi} / \mathrm{mmol})$ (Moravek Biochemicals, Brea, CA, USA), S-[methyl $\left.-{ }^{14} \mathrm{C}\right]-$ adenosyl-L-methionine $(55 \mathrm{mCi} / \mathrm{mmol}$ ) (American Radiolabeled Chemicals Inc., St. Louis, MO, USA), Dulbecco's modified Eagle's medium (DMEM), fetal bovine serum (FBS) (Hyclone, Logan, UT, USA), 9-(2-phosphonylmethoxyethyl) adenine (PMEA) (Gilead, Forest City, CA, USA), Coomassie brilliant blue (CBB) stain solution (Bio-Rad, Hercules, CA, USA), monoclonal antibodies against P-gp (Signet Laboratories Inc., Dedham, MA, USA) and against BCRP/ABCG2 (A.G. Scientific Inc., San Diego, CA, USA) were purchased. Allopurinol, 2-mercaptopurine (2-MP), 6-MP, 6-TG, cisplatin, creatine phosphokinase, Cytarabine (AraC), 1-(4,5-dimethylthiazol2-yl)-3,5-diphenylformazan(MTT), ethylenediamine tetraacetic acid (EDTA), etoposide, glutathione, glycine, mitoxantrone (MX), 6-methylmercaptopurine riboside (6-MMPR), MTX, phosphocreatine, 5-phosphoribosyl-1-pyrophosphate, potassium phosphate and vincristine were obtained from Sigma-Aldrich (St. Louis, MO, USA). The monoclonal antibodies against MRP1 (32), MRP4 (13,14), hENT1, hENT2, hCNT2 and hCNT3 $(20,34,35)$ and polyclonal antibodies against MRP5 (33) and MRP8 (16) were previously described.

Cell culture. BCR/ABL-positive CML cell line K562 (American Type Culture Collection, Manassas, VA, USA) (termed K562 cells) is a human cell line that was originally derived from a CML patient in blast crisis. A 6-MP-resistant sub-clone (K562-MP5) was selected from K562 cells by growth in the presence of increasing concentrations of 6-MP, up to a final concentration of $5 \mathrm{mM}$ which was achieved over a 3-month period. K562-MP5 cells were grown in drug-free medium for at least 2 weeks prior to being used for experiments. K562MP5 cells exhibited a stable phenotype as shown by the MTT assay after growth in the absence of the drug for 3 months. HEK293/pcDNA and HEK293/ABCG2-R2 cell lines were kindly provided by Drs Susan Bates and Robert Robey (NCI, NIH, Bethesda, MD, USA) and were previously described (36). The cells were subcultured twice weekly at $37^{\circ} \mathrm{C}$ in a $5 \% \mathrm{CO}_{2}$ humidified atmosphere in growth medium comprising DMEM supplemented with heat-inactivated $10 \%$ FBS.

Analysis of drug sensitivity by MTT assay. Cell viability was determined by a modified MTT cytotoxicity assay as previously described (37). In brief, cells were plated into 96-well tissue culture plates $\left(1.2 \times 10^{4}\right.$ cells/well $)$ in $0.2 \mathrm{ml}$ medium. Following cell incubation at $37^{\circ} \mathrm{C}$ in a $5 \% \mathrm{CO}_{2}$ humidified atmosphere in DMEM supplemented with heat-inactivated $10 \%$ FBS for $70 \mathrm{~h}, 20 \mu \mathrm{l}$ of MTT ( $2 \mathrm{mg} / \mathrm{ml}$ PBS) was added to each well. The plates were incubated for another $2 \mathrm{~h}$. The cells were collected in microcentrifuge tubes and the media were removed by centrifugation at $1,500 \mathrm{x}$ g for $2 \mathrm{~min}$. Cell pellets were washed twice with ice-cold phosphate-buffered saline (PBS) and $100 \mu \mathrm{l}$ of dimethylsulfoxide (DMSO) was added into each tube at room temperature to solubilize the formazan crystals. The dissolved formazan was then transferred into the fresh 96-well plates and the absorbance was determined at $570 \mathrm{~nm}$ using an Opsys microplate reader (Dynex Technologies Inc., Chantilly, VA, USA).

Analysis of accumulation and efflux of $\left[{ }^{14} C\right] 6-M P$. Drug accumulation and efflux experiments were performed with a slight modification of methods previously described (14). In brief, for the accumulation experiments, $2 \times 10^{6}$ cells/well of K562 or K562-MP5 cells were seeded in triplicate in 24-well plates and incubated at $37^{\circ} \mathrm{C}$ with $10 \mu \mathrm{M}\left[{ }^{14} \mathrm{C}\right] 6-\mathrm{MP}$ in complete medium for $60 \mathrm{~min}$. Cells were collected in microcentrifuge tubes and the media were removed by centrifugation at $1,500 \mathrm{x} g$ for 2 min. Cell pellets were washed 3 times with ice-cold PBS, and then radioactivity was measured by liquid scintillation counting. For the efflux experiments, $2 \times 10^{6}$ cells/well of K562 or K562-MP5 cells were seeded in triplicate in 24-well plates and were incubated at $37^{\circ} \mathrm{C}$ in an energy depletion medium (glucose-free, pyruvate-free DMEM containing 10\% dialyzed FBS, $5 \mathrm{mM}$ sodium azide) containing $10 \mu \mathrm{M}\left[{ }^{14} \mathrm{C}\right] 6-\mathrm{MP}$ for $60 \mathrm{~min}$. The cells were then washed 3 times with ice-cold PBS and were incubated at $37^{\circ} \mathrm{C}$ for 30 and $60 \mathrm{~min}$ in complete medium without radiolabeled drugs. Cell-associated radioactivity was determined at the end of $60-\mathrm{min}$ incubation in an energy depletion medium and at various subsequent time points.

Preparation of membrane vesicles and Western blot analysis. Membrane vesicles were prepared by the nitrogen cavitation method as previously described (14). Briefly, cells from culture were washed twice with ice-cold PBS and once with vesicle buffer [10 mM Tris-HC1 ( $\mathrm{pH} 7.4$ ), $0.25 \mathrm{M}$ sucrose, $0.2 \mathrm{mM}$ $\mathrm{CaCl}_{2}$ ], and then equilibrated at $4^{\circ} \mathrm{C}$ under nitrogen pressure at $400 \mathrm{psi}\left(25 \mathrm{~kg} / \mathrm{cm}^{2}\right)$ for $15 \mathrm{~min}$. The cell homogenate was added with EDTA to a final concentration of $1 \mathrm{mM}$, diluted with dilution buffer $[10 \mathrm{mM}$ Tris- $\mathrm{HCl}$ ( $\mathrm{pH}$ 7.4), $0.25 \mathrm{M}$ sucrose] and centrifuged at $1,500 \mathrm{x} \mathrm{g}$ for $10 \mathrm{~min}$ to remove nuclei and unlysed cells. The supernatant was layered onto a $35 \%$ sucrose cushion $[10 \mathrm{mM}$ Tris- $\mathrm{HC} 1$ ( $\mathrm{pH} 7.4), 35 \%$ sucrose, $1 \mathrm{mM}$ EDTA] and centrifuged at $16,000 \mathrm{x} \mathrm{g}$ for $30 \mathrm{~min}$. The interface was collected and then centrifuged at $100,000 \mathrm{x} \mathrm{g}$ for 
$45 \mathrm{~min}$. The vesicle pellet was re-suspended in dilution buffer by sequentially using a 26-gauge needle. Vesicles were stored at $-80^{\circ} \mathrm{C}$ until use. The protein concentrations were determined using the Bradford method (38). Proteins of membrane vesicles were resolved by 4-12\% SDS-PAGE and transferred to nitrocellulose filters. P-gp, BCRP/ABCG2, and MRPs 1, 4, 5 and 8 were detected using monoclonal antibodies against P-gp, BCRP/ABCG2, MRP1 and MRP4 (at dilutions of 1:200, 1:500, $1: 2,000$ and 1:1,000, respectively) and polyclonal antibodies against MRP5 and MRP8 (at dilutions of 1:500) and horseradish peroxidase (HRP)-conjugated secondary antibodies (all at a dilution of 1:1,000). hENT1, hENT2, hCNT2 and hCNT3 were detected using monoclonal antibodies (all at a dilution of 1:10) and HRP-conjugated secondary antibodies (all at a dilution of 1:1,000). Enhanced chemiluminescence (Amersham Biosciences Corp., Piscataway, NJ, USA) was used for visualization. Since actin, the normally used control, was not detectable in the samples prepared from the membrane vesicles, $\mathrm{CBB}$ staining was used to demonstrate approximately equal loading.

RT-PCR assay. The procedures and protocols from RNeasy ${ }^{\circledR}$ mini handbook were followed. Total cellular RNA was isolated from K562 and K562-MP5 cells using Perfect RNA ${ }^{\mathrm{TM}}$ kit from the Eppendorf Co. (Westbury, NY, USA). The total RNA concentration and purity were determined by measuring absorbance at 260 and $280 \mathrm{~nm}$ with the UV T60 spectrophotometer. The integrity of total RNA was then checked by agarose gel electrophoresis and ethidium bromide staining. For RT-PCR, $1 \mu \mathrm{g}$ total RNA samples was used for cDNA synthesis by using cMaster RTplusPCR system and cMaster RT kit. The primer sequence of MRP4 was: sense 5'-TGATGAGCCGTATGTTTTGC-3' and antisense 5'-CTT CGGAACGGACTTGACAT-3'. The primer sequence of the internal control, glyceraldehyde 3-phosphate dehydrogenase (GAPDH), was: sense 5'-GCCAAAAGGGTCATCATCTC-3' and antisense 5'-GTAGAGGCAGGGATGATGTTC-3'. The primer sequence of MDR1 was: sense 5'-ATATCAGCAG CCCACATCAT-3' and antisense 5'-GAAGCACTGGGATG TCCG GT-3'. One-step RT-PCR was carried out for 35 cycles as follows: reverse transcription at $50^{\circ} \mathrm{C}$ for $30 \mathrm{~min}$, initial denaturation at $94^{\circ} \mathrm{C}$ for $2 \mathrm{~min}$, template denaturation at $94^{\circ} \mathrm{C}$ for $15 \mathrm{sec}$, primer annealing at $52^{\circ} \mathrm{C}$ for $20 \mathrm{sec}$ and primer extension/elongation at $68^{\circ} \mathrm{C}$ for $30 \mathrm{sec}$. The PCR products were separated by denaturing agarose gel electrophoresis. The gel was stained with $1 \mu \mathrm{g} / \mathrm{ml}$ ethidium bromide and the bands were visualized using the ECL chemiluminescence system.

Vesicular transport experiments. The vesicular transport experiments of $\left[{ }^{3} \mathrm{H}\right] \mathrm{MTX}$ were performed using the rapid filtration method as previously described $(16,36)$. Membrane vesicles prepared from HEK293/pcDNA and HEK293/ABCG2-R2 cells were used as negative and positive controls, respectively. Transport experiments were carried out in medium containing membrane vesicles $(10 \mu \mathrm{g}), 0.25 \mathrm{M}$ sucrose, $10 \mathrm{mM}$ Tris- $\mathrm{HCl}$ (pH 7.4), $10 \mathrm{mM} \mathrm{MgCl}_{2}, 4 \mathrm{mM}$ ATP or $4 \mathrm{mM} \mathrm{AMP,} 10 \mathrm{mM}$ phosphocreatine, $100 \mu \mathrm{g} / \mathrm{ml}$ creatine phosphokinase, and $0.5 \mu \mathrm{M}$ radiolabeled MTX, in a total volume of $50 \mu 1$. Reactions were carried out at $37^{\circ} \mathrm{C}$ for $10 \mathrm{~min}$ and were stopped by the addition of $3 \mathrm{ml}$ of ice-cold stop solution [0.25 M sucrose, $100 \mathrm{mM} \mathrm{NaCl}$, and $10 \mathrm{mM}$ Tris- $\mathrm{HCl}(\mathrm{pH}$ 7.4)]. For the rapid filtration step, samples were passed through $0.22 \mu \mathrm{m}$ GVWP filters (Millipore Corp., Billerica, MA, USA) pre-soaked in the stop solution under vacuum. The filters were washed 3 times with $3 \mathrm{ml}$ of ice-cold stop solution and dried at room temperature for $30 \mathrm{~min}$. Radioactivity was measured using a liquid scintillation counter. Rates of net ATP-dependent transport were determined by subtracting the values obtained in the presence of $4 \mathrm{mM}$ AMP from those obtained in the presence of $4 \mathrm{mM}$ ATP.

HGPRT activity. HGPRT activity in cell lysates was estimated by the formation of $\left[{ }^{14} \mathrm{C}\right]$ inosine monophosphate from $\left[{ }^{14} \mathrm{C}\right]$ hypoxanthine by a modification of a previously described method $(28,39)$ according to the following protocol: $20 \mu \mathrm{l}$ cell lysates, $10 \mu \mathrm{l}$ water, and $70 \mu \mathrm{l}$ cocktail (20 $\mu \mathrm{l}$ of $0.5 \mathrm{M}$ glycine buffer, $10 \mu \mathrm{l}$ of $50 \mathrm{mM} \mathrm{MgCl}_{2}, 10 \mu \mathrm{l}$ of $10 \mathrm{mM}$ 5-phosphoribosyl-1-pyrophosphate, $10 \mu \mathrm{l}$ of $1.5 \mathrm{mM}\left[{ }^{14} \mathrm{C}\right]$ hypoxanthine, and $20 \mu \mathrm{l}$ water) were mixed and incubated for $15 \mathrm{~min}$ at room temperature. The reaction was stopped by placing mixtures on ice and adding $5 \mu \mathrm{l}$ of $0.25 \mathrm{M}$ EDTA. Sample mixture or standard $(20 \mu \mathrm{l})$ (containing the known amount of $\left[{ }^{14} \mathrm{C}\right]$ inosine monophosphate) were detected on polyethyleneimine cellulose paper, dried, and washed 3 times with $3 \mathrm{ml}$ of $1 \mathrm{mM}$ $\mathrm{NH}_{4} \mathrm{HCO}_{3}$. The bound radioactivity was counted in $5 \mathrm{ml}$ of liquid scintillation solution.

TPMT activity. TPMT activity was analyzed by a modification of a previously described radiochemical assay $(28,40)$. Cell lysate $(100 \mu \mathrm{l})$ was incubated with $7.5 \mathrm{mM}$ 6-MP, $15 \mathrm{mM}$ glutathione, $50 \mu \mathrm{M}$ allopurinol, $1 \mathrm{M}$ potassium phosphate (pH 7.5), and $23 \mu \mathrm{M}(55 \mu \mathrm{Ci} / \mu \mathrm{mol}) \mathrm{S}$-[methyl- $\left.{ }^{14} \mathrm{C}\right]$-adenosylL-methionine (in a total volume of $160 \mu \mathrm{l}$ ) for $60 \mathrm{~min}$. The radiolabeled 6-MP that was produced was extracted with $20 \%$ isoamyl alcohol in toluene, and counted in $5 \mathrm{ml}$ of liquid scintillation solution. Results were normalized to $1 \mathrm{mg}$ protein, based on the amount of protein used for the $100 \mu \mathrm{l}$ of lysate. One unit of enzyme activity represents the formation of $1 \mathrm{nmol}$ of 6-MP per hour of incubation.

Statistical analysis. The data were analyzed by the unpaired Student's t-test and $\mathrm{P}<0.05$ was considered to be statistically significant.

\section{Results}

Drug resistance profile of 6-MP-resistant K562 cells. To investigate the mechanisms of cellular resistance to 6-MP in CML, a 6-MP-resistant cell line was established using the CML K562 cells. K562 cells were made resistant to 6-MP by stepwise selection in 6-MP. Analysis of drug sensitivity of the resulting cell line K562-MP5 indicated that K562-MP5 cells were 339-fold more resistant to 6-MP compared with parental K562 cells (Table I, Fig. 1A). K562-MP5 cells were highly cross-resistant to other nucleobase analogs such as 6-TG and exhibited lower levels of resistance to 2-MP and PMEA (Table I, Fig. 1). K562-MP5 cells were not resistant to AraC, but were 25-fold more sensitive to 6-MMPR. In addition, K562-MP5 cells were resistant to the non-nucleobase agents MX, vincristine and cisplatin, but were more sensitive to MTX. 
Table I. Drug resistance profile of K562-MP5 cells ${ }^{\mathrm{a}}$.

\begin{tabular}{|c|c|c|c|}
\hline \multirow[t]{2}{*}{ Reagents } & \multicolumn{2}{|c|}{$\mathrm{IC}_{50}(\mu \mathrm{M})$} & \multirow[t]{2}{*}{ Relative resistance } \\
\hline & K562 & K562-MP5 & \\
\hline 6-MP & $22.6 \pm 5.2$ & $7647 \pm 135^{\mathrm{e}}$ & 339.0 \\
\hline 6-TG & $4.3 \pm 1.3$ & $387 \pm 123^{\mathrm{e}}$ & 91.0 \\
\hline 2-MP & $1369 \pm 158$ & $7245 \pm 329^{d}$ & 5.3 \\
\hline PMEA & $346 \pm 111$ & $805 \pm 127^{\mathrm{c}}$ & 2.3 \\
\hline AraC & $6.3 \pm 2.0$ & $7.0 \pm 2.2$ & 1.1 \\
\hline 6-MMPR & $2.4 \pm 0.4$ & $0.10 \pm 0.01^{\mathrm{e}}$ & 0.04 \\
\hline MX & $0.010 \pm 0.003$ & $0.015 \pm 0.002$ & 1.5 \\
\hline Vincristine & $0.13 \pm 0.04$ & $0.41 \pm 0.11^{\mathrm{d}}$ & 3.2 \\
\hline Cisplatin & $149 \pm 33$ & $91 \pm 38^{c}$ & 2.6 \\
\hline MTX & $1.54 \pm 0.12$ & $0.64 \pm 0.07^{\mathrm{d}}$ & 0.4 \\
\hline
\end{tabular}

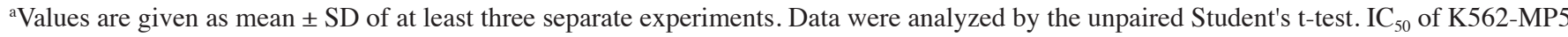
cells differed significantly from K562 cells at ${ }^{\mathrm{c}} \mathrm{P}<0.05,{ }^{\mathrm{d}} \mathrm{P}<0.01$ and ${ }^{\mathrm{e}} \mathrm{P}<0.001$. ${ }^{\mathrm{b}}$ Relative resistance was obtained by dividing the IC $\mathrm{C}_{50}$ value $\mathrm{K} 562$ cells by the $\mathrm{IC}_{50}$ value of K562-MP5 cells for a particular treatment.

A

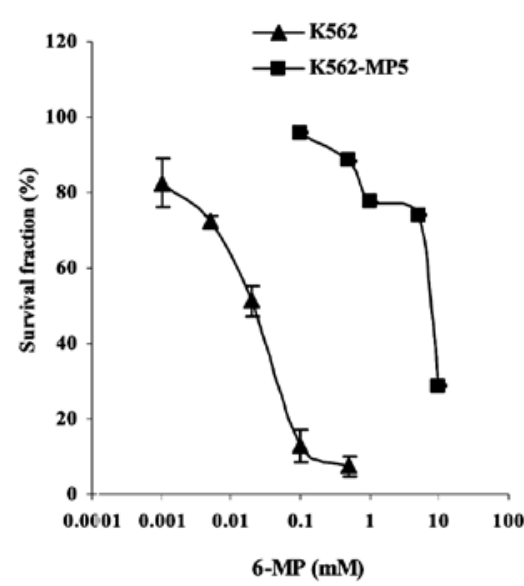

C

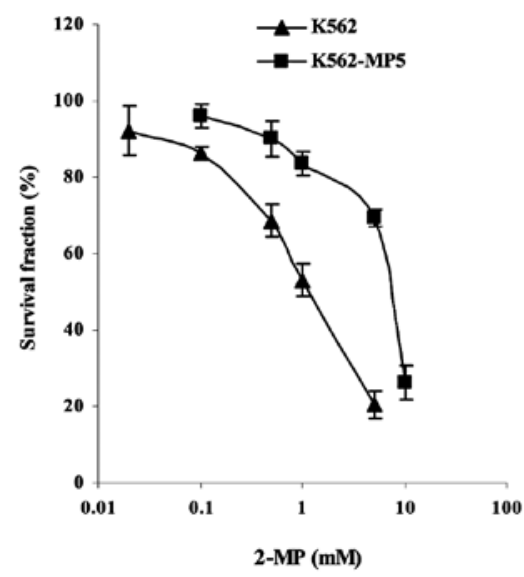

B

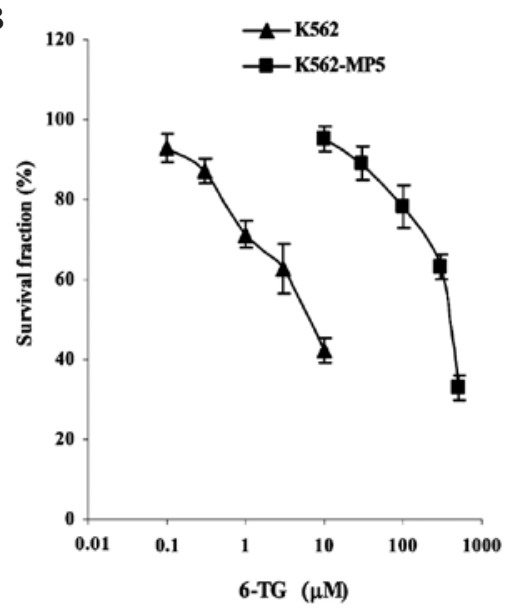

D

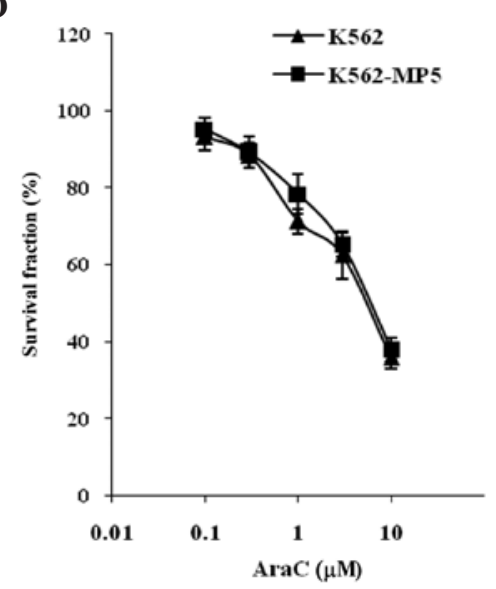

Figure 1. Sensitivity of K562 (ی) and K562-MP5 (ם) cells to 6-MP, 6-TG, 2-MP or AraC was analyzed using the MTT cytotoxicity assay as described in Materials and methods. Data points are the mean \pm SD of at least three separate experiments.

Analysis of accumulation and efflux of $\left[{ }^{14} C\right] 6-M P$. To determine whether decreased accumulation of the drug was involved in the resistance of K562-MP5 cells, the accumula- tion of radioactivity derived from $\left[{ }^{14} \mathrm{C}\right] 6-\mathrm{MP}$ was analyzed. The pilot testing had revealed that the maximum accumulation of $\left[{ }^{14} \mathrm{C}\right] 6-\mathrm{MP}$ and its metabolites was achieved at $60 \mathrm{~min}$. 


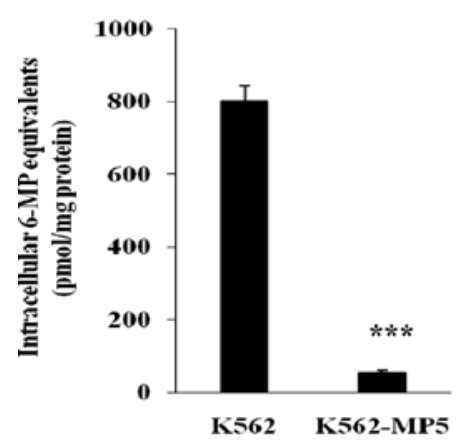

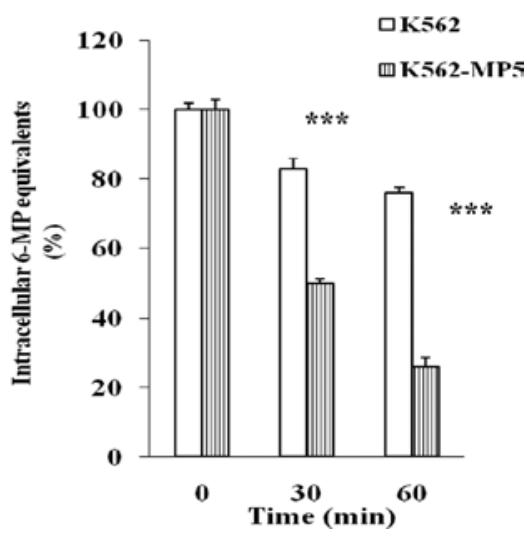

Figure 2. Time-dependent accumulation and efflux of $\left[{ }^{14} \mathrm{C}\right] 6-\mathrm{MP}$ and/or its metabolites in K562 and K562-MP5 cells. (A) Accumulation of $\left[{ }^{14} \mathrm{C}\right] 6-\mathrm{MP}$ and its metabolites at $60 \mathrm{~min}$ in K562 and K562-MP5 cells in complete medium. Values are given as mean \pm SD, n=3. Data were analyzed by the unpaired Student's t-test. Accumulation of $\left[{ }^{14} \mathrm{C}\right] 6-\mathrm{MP}$ and its metabolites at $60 \mathrm{~min}$ in K562-MP5 cells decreased significantly compared with $\mathrm{K} 562$ cells at ${ }^{* * *} \mathrm{P}<0.001$. (B) Time course of efflux of $\left[{ }^{14} \mathrm{C}\right] 6-\mathrm{MP}$ and its metabolites in $\mathrm{K} 562$ and K562-MP5 cells after various efflux times. Values are given as mean $\pm \mathrm{SD}$, $\mathrm{n}=3$. The percentages of retained 6-MP equivalents after 30 and 60 min efflux are indicated in K562 and K562-MP5 cells relative to that at 0 time. Data were analyzed by the unpaired Student's t-test. After 30 and 60 min efflux, the retained 6-MP equivalents in K562-MP5 cells decreased significantly compared with K562 cells at **** $\mathrm{P}<0.001$

The accumulation of $\left[{ }^{14} \mathrm{C}\right] 6-\mathrm{MP}$ equivalents was markedly reduced in K562-MP5 compared with K562 cells (Fig. 2A), with K562-MP5 cells accumulating only $6 \%$ of $\left[{ }^{14} \mathrm{C}\right] 6-\mathrm{MP}$ equivalents in comparison to K562 cells.

To further dissect the basis of the decreased accumulation of $\left[{ }^{14} \mathrm{C}\right] 6-\mathrm{MP}$ equivalents in K562-MP5 cells, separate efflux experiments were performed. K562 and K562-MP5 cells were allowed to accumulate $\left[{ }^{14} \mathrm{C}\right] 6-\mathrm{MP}$ equivalents in the energy depletion medium, which prevents the activity of ATP-dependent efflux pumps. After $60 \mathrm{~min}$, the intracellular accumulation was comparable in K562 and K562-MP5 cells. Cells were then switched to complete medium to allow efflux, and intracellular radioactivity was measured after 30 and $60 \mathrm{~min}$. After $30 \mathrm{~min}$ efflux, $50 \%$ of the accumulated 6-MP equivalents were released from K562-MP5 cells, whereas only $16 \%$ of the accumulated 6-MP equivalents were released from K562 cells. After 60 min efflux, $73 \%$ of the accumulated 6-MP equivalents were released from K562-MP5 cells, whereas only $25 \%$ of the accumulated 6-MP equivalents were released from K562 cells (Fig. 2B). These results indicate that increased efflux was involved in the reduced cellular accumulation in K562-MP5 cells.

Expression of P-gp, MRPs, BCRP/ABCG2 and NTs. The increased efflux exhibited by K562-MP5 cells, in combination with cross-resistance to vincristine, suggested that P-gp is involved in the resistance phenotype of the cell line. As shown in Fig. 3A, P-gp was markedly over-expressed in K562-MP5 cells. However, the expression of MRP4, a pump which was previously found to be over-expressed in ALL cells made resistant to 6-MP (26), was similar in K562 and K562-MP5 cells. Expression of MRP1, MRP5, MRP8 and BCRP/ABCG2 was undetectable (data not shown) and the levels of influx NTs (hENT1, hENT2, hCNT2 and hCNT3) were similar in the two cell lines (Fig. 3A).

Expression of MDR1 mRNA levels in K562 and K562-MP5 cells. The RT-PCR assay was used to ascertain whether the mRNA levels of MDR1 were up-regulated in the K562-
MP5 cells. As shown in Fig. 3B, MDR1 mRNA levels were significantly increased in K562-MP5 cells compared with K562 cells.

Transport of $\left[{ }^{3} H\right] M T X$. P-gp is an ATP-dependent membrane efflux pump, which is able to transport anti-cancer drugs such as the established P-gp substrate MTX, leading to drug resistance. $\mathrm{P}$-gp-dependent transport activity was examined by analyzing the ability of the pump to transport $\left[{ }^{3} \mathrm{H}\right] \mathrm{MTX}$ into inside-out membrane vesicles. The ATP-dependent MTX transport with membrane vesicles prepared from K562-MP5 cells was significantly higher than that from K562 cells with a transport rate of $\left[{ }^{3} \mathrm{H}\right] \mathrm{MTX} 0.42$ and $0.05 \mathrm{pmol} / \mathrm{min} / \mathrm{mg}$ protein by K562-MP5 and K562 membrane vesicles, respectively (Fig. 4).

Enzyme activities of HGPRT and TPMT in K562 and K562-MP5 cells. Since HGPRT and TPMT are the two key enzymes associated with the metabolism of 6-MP, the activity of these enzymes was analyzed. HGPRT activity is similar in K562 and K562-MP5 cells, with activity of $1360 \pm 200$ and $1360 \pm 180 \mathrm{pmol} / \mathrm{min} / \mathrm{mg}$ protein, respectively. TPMT activity was also similar in K562 and K562-MP5 cells, with activity of $0.489 \pm 0.063$ and $0.556 \pm 0.110 \mathrm{U} / \mathrm{mg}$ protein, respectively.

\section{Discussion}

The studies of Hart et al and Wuchter et al showed that P-gp may contribute to the poor prognosis of adult T-cell leukemia and adult acute myeloid leukemia $(41,42)$. Kuwazuru et al examined the P-gp expression levels in fresh leukemia cells from CML patients in blast crisis and found that 6 out of 11 patients ( 9 in the refractory state) were P-gp-positive. In addition, these authors showed that P-gp-expression levels correlate with the response of patients to chemotherapy (43). However, none of the aforementioned studies attempted to elucidate the mechanisms underlying the P-gp function. We recently demonstrated that the up-regulation of MRP4 and 
A

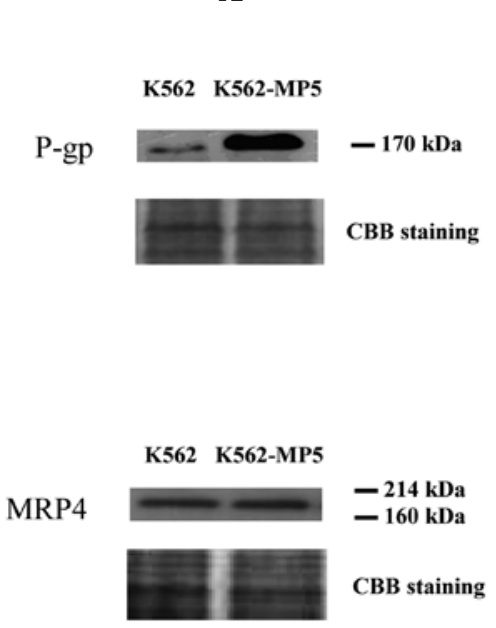

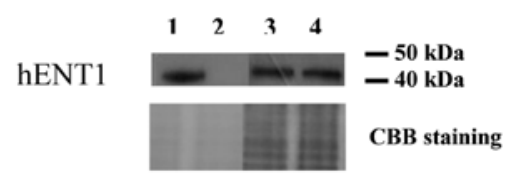

hENT2

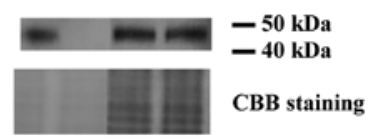

hCNT2

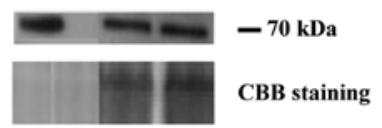

hCNT3

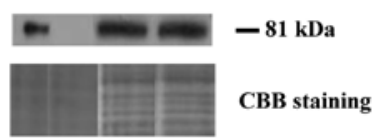

B

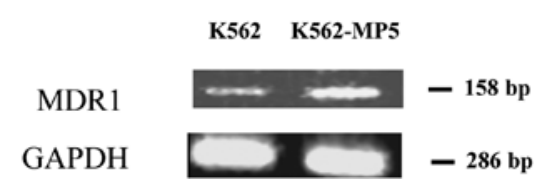

Figure 3. (A) Western blot analysis of P-gp, MRP4, hENT1/2 and hCNT2/3 in membrane vesicle preparations from K562 and K562-MP5 cells. Membrane vesicles were prepared as described in Materials and methods from sensitive and resistant cells (K562 and K562-MP5) and, as controls, from yeast cells producing recombinant hENT1/2 or hCNT2/3. Protein was resolved by SDS-PAGE on 4-12\% gel and electrotransferred to nitrocellulose membranes. Mobilities of the molecular mass markers are indicated in kilodaltons. In the right panel, lanes 1, 2, 3 and 4 are yeast cells highly producing the indicated protein (positive control), yeast cells without the indicated protein (negative control), K562 and K562-MP5 cells, respectively. Proteins of $20 \mu \mathrm{g} / \mathrm{lane}$ [for the positive and negative controls of hENT1/2 $(0.2 \mu \mathrm{g} /$ lane $)$ and hCNT2/3 $(0.5 \mu \mathrm{g} /$ lane $)]$ were loaded. The bottom panel is a section of an identical gel stained with Coomassie brilliant blue to demonstrate approximately equal loading. (B) RT-PCR analysis of mRNA expression levels of MDR1 in K562 and K562-MP5 cells.

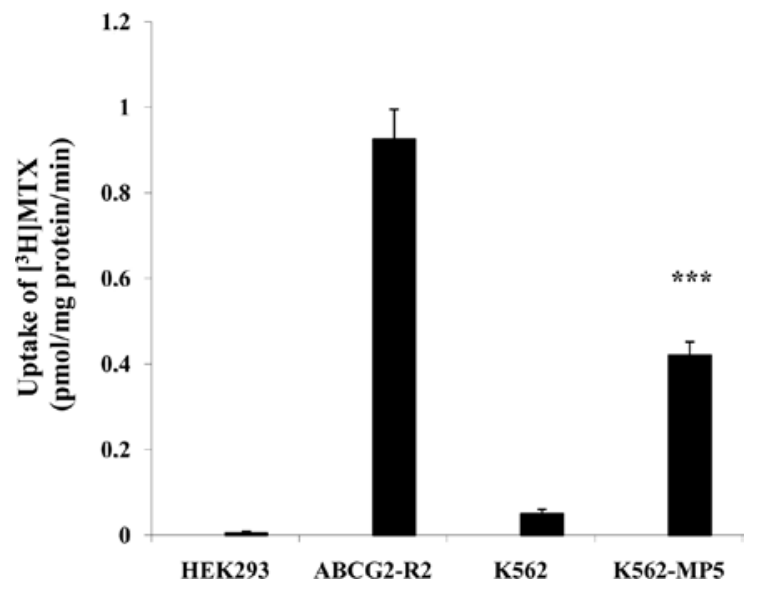

Figure 4. Uptake of $\left[{ }^{3} \mathrm{H}\right] \mathrm{MTX}$ into inside-out membrane vesicles derived from K562 and K562-MP5 cells. Values are given as mean \pm SD, $n=3$. Membrane vesicles prepared from HEK293/pcDNA and HEK293/ABCG2-R2 are used as negative and positive controls, respectively. Data were analyzed by the unpaired Student's t-test. The ATP-dependent uptake of $\left[{ }^{3} \mathrm{H}\right] \mathrm{MTX}$ in K562-MP5 cells increased significantly compared with K562 cells at ${ }^{* * * *} \mathrm{P}<0.001$.

down-regulation of influx transporters hENT1, hCNT2 and hCNT3, which lead to decreased accumulation of 6-MP in cells with acquired resistance to 6-MP, play a significant role in 6-MP resistance in ALL (28). To investigate whether or not these drug resistance factors also play a potential role in CML, we established a resistant cell line (K562-MP5) by stepwise selection using a CML cell line (K562).

The present results showed that K562-MP5 cells were highly resistant to 6-MP in comparison with the parental K562 cells. In addition, K562-MP5 cells were cross-resistant to other anti-cancer drugs such as 6-TG, 2-MP, vincristine, MX, cisplatin and anti-hepatitis B agent PMEA (Table I, Fig. 1). P-gp and MDR1 mRNA levels were up-regulated in K562-MP5 cells (Fig. 3), which is consistent with the results of Zeng et al who showed that high expression of P-gp in the surface membranes of cells is responsible for resistance to 6-MP (44). Compared to K562 cells, K562-MP5 cells had significantly lower accumulation and higher efflux of $\left[{ }^{14} \mathrm{C}\right] 6-\mathrm{MP}$ equivalents (Fig. 2). Transport of $\left[{ }^{3} \mathrm{H}\right] \mathrm{MTX}$ into membrane vesicles prepared from K562-MP5 cells was significantly higher than that of K562 cells (Fig. 4). Although MTX is also a substrate of MRPs 1, 2, 3, 4 and BCRP/ABCG2, only P-gp was significantly up-regulated in K562-MP5 cells (Fig. 3A). The expression levels of MRP4 were similar in K562 and K562-MP5 cells (Fig. 3A). Furthermore, MRP1 and BCRP/ABCG2 were not detected in K562 and K562MP5 cells (data not shown). No studies are currently available showing that MRP2 and MRP3 are expressed in CML cells. The results of the present study validate the function of P-gp as an efflux transporter and suggest that over-expression of P-gp confers resistance to 6-MP in CML. 
These results are in contrast to our previous results which showed that the levels of hENT1, hCNT2 and hCNT3 in 6-MP-resistant CEM-MP5 cells were decreased in comparison to levels in parental CEM cells (28), and that levels of hENT1, hENT2, hCNT2 and hCNT3 were similar in K562 and K562-MP5 cells (Fig. 2A). Therefore, influx NTs are not involved in the decreased accumulation of 6-MP and its metabolites in K562-MP5 cells. Additionally, unlike our previous study, which showed that TPMT activity was higher in 6-MP-resistant CEM-MP5 cells, neither HGPRT nor TPMT, the key enzymes involved in the metabolism of 6-MP, showed a difference in activity between K562-MP5 cells and K562 cells (data shown in Results). The results therefore suggest that plasma membrane influx NTs and the enzymes involved in 6-MP metabolism play a role in the resistance of 6-MP in ALL (28), but not in CML.

Consistent with our previous findings in CEM-MP5 and CEM cells (28), K562-MP5 cells were found to be significantly responsive to 6-MMPR and MTX compared to the wild-type K562 cells (Table I). 6-MMPR, a methylated metabolite of 6-MP, is able to bypass resistance to the parental drug. This phenomenon is explained by the recent findings that the 6-MP resistant cells have a reduced purine nucleotide synthesis and lower levels of ribonucleoside triphosphates compared with the parental cells $(5,7)$. In contrast, the influx of 6-MMPR into these cells was not significantly altered (5,7). K562-MP5 cells, which express higher levels of P-gp, were significantly more responsive to MTX than K562 cells. Two possible explanations for this phenomenon are: i) P-gp can only efflux the MTX monoglutamate $(45,46)$; however, after incubating the cells for $72 \mathrm{~h}$, the predominance of MTX in the K562-MP5 cells had been converted to MTX polyglutamates, and ii) K562-MP5 cells produced higher levels of MTX polyglutamates than the K562 cells, and the MTX polyglutamates potently inhibit the de novo biosynthesis of purines.

In conclusion, the present results indicate that the upregulation of P-gp, which contributes to the decreased uptake and increased efflux of 6-MP and its metabolites, plays a critical role in 6-MP resistance in CML. These findings suggest that the mechanisms of 6-MP resistance in CML are different from those of ALL.

\section{Acknowledgements}

This study was supported by funds from St. John's University Research Seed Grant (no. 579-1110-7002, Z.S. Chen), the Department of Pharmaceutical Sciences, and the Canadian Cancer Society Research Institute (C.E. Cass). Z. Shi thanks the fellowship from Sun Yat-Sen University (China) for study in the USA. We thank Drs Susan E. Bates and Robert W. Robey (NIH, Bethesda, MD, USA) for providing HEK293/pcDNA cells and HEK293/ABCG2-R2 transfectant cells.

\section{References}

1. Ambudkar SV, Dey S, Hrycyna CA, Ramachandra M, Pastan I and Gottesman MM: Biochemical, cellular, and pharmacological aspects of the multidrug transporter. Annu Rev Pharmacol Toxicol 39: 361-398, 1999.
2. Deeley RG, Westlake C and Cole SP: Transmembrane transport of endo- and xenobiotics by mammalian ATP-binding cassette multidrug resistance proteins. Physiol Rev 86: 849-899, 2006.

3. Cui Y, Konig J, Buchholz JK, Spring H, Leier I and Keppler D: Drug resistance and ATP-dependent conjugate transport mediated by the apical multidrug resistance protein, MRP2, permanently expressed in human and canine cells. Mol Pharmacol 55: 929-937, 1999.

4. Kruh GD and Belinsk MG: The MRP family of drug efflux pumps. Oncogene 22: 7537-7552, 2003.

5. Elion GB: The purine path to chemotherapy. Science 244: 41-47, 1989.

6. Elgemeie GH: Thioguanine, mercaptopurine: their analogs and nucleosides as antimetabolites. Curr Pharm Des 9: 2627-2642, 2003.

7. Fotoohi AK, Wrabel A, Moshfegh A, Peterson C and Albertioni F: Molecular mechanisms underlying the enhanced sensitivity of thiopurine-resistant T- lymphoblastic cell lines to methyl mercaptopurine-riboside. Biochem Pharmacol 72: 816-823, 2006.

8. Juliano RL and Ling V: A surface glycoprotein modulating drug permeability in Chinese hamster ovary cell mutants. Biochim Biophys Acta 455: 152-162, 1976.

9. Plasschaert SL, de Bont ES, Boezen M, et al: Expression of multidrug resistance-associated proteins predicts prognosis in childhood and adult acute lymphoblastic leukemia. Clin Cancer Res 11: 8661-8668, 2005.

10. Del Principe MI, del Poeta G, Maurillo L, et al: P-glycoprotein and BCL-2 levels predict outcome in adult acute lymphoblastic leukaemia. Br J Haematol 121: 730-738, 2003.

11. Cole SP, Bhardwaj G, Gerlach JH, et al: Overexpression of a transporter gene in a multidrug-resistant human lung cancer cell line. Science 258: 1650-1654, 1992.

12. Doyle LA, Yang W, Abruzzo LV, et al: A multidrug resistance transporter from human MCF-7 breast cancer cells. Proc Natl Acad Sci USA 95: 15665-15670, 1998.

13. Lee K, Klein-Szanto AJ and Kruh GD: Analysis of the MRP4 drug resistance profile in transfected NIH3T3 cells. J Natl Cancer Inst 92: 1934-1940, 2000.

14. Chen ZS, Lee K and Kruh GD: Transport of cyclic nucleotides and estradiol 17-beta-D-glucuronide by multidrug resistance protein 4: resistance to 6-mercaptopurine and 6-thioguanine. J Biol Chem 276: 33747-33754, 2001.

15. Abbas-Terki T, Blanco-Bose W, Deglon N, Pralong W and Aebischer P: Lentiviral-mediated RNA interference. Hum Gene Ther 13: 2197-2201, 2002.

16. Guo Y, Kotova E, Chen ZS, Lee K, Hopper-Borge E, Belinsky MG and Kruh GD: MRP8, ATP-binding cassette C11 (ABCC11), is a cyclic nucleotide efflux pump and a resistance factor for fluoropyrimidines 2', 3'-dideoxycytidine and 9'-(2'-phosphonylmethoxyethyl) adenine. J Biol Chem 278: 29509-29514, 2003.

17. Dean M, Hamon Y and Chimini G: The human ATP-binding cassette (ABC) transporter superfamily. J Lipid Res 42: 1007-1017, 2001.

18. Dean M, Rzhetsky A and Allikmets R: The human ATP-binding cassette (ABC) transporter superfamily. Genome Res 11: 1156-1166, 2001.

19. Annino L, Vegna ML, Camera A, et al: Treatment of adult acute lymphoblastic leukemia (ALL): long-term follow-up of the GIMEMA ALL 0288 randomized study. Blood 99: 863-871, 2002.

20. Zhang J, Visser F, Vickers MF, et al: Uridine binding motifs of human concentrative nucleoside transporters 1 and 3 produced in Saccharomyces cerevisiae. Mol Pharmacol 64: 1512-1520, 2003.

21. Larson RA: The U.S. trials in adult acute lymphoblastic leukemia. Ann Hematol 83 (Suppl 1): S127-S128, 2004.

22. Norris MD, Smith J, Tanabe K, et al: Expression of multidrug transporter MRP4/ABCC4 is a marker of poor prognosis in neuroblastoma and confers resistance toirinotecan in vitro. Mol Cancer Ther 4: 547-553, 2005.

23. Wijnholds J, Mol CA, van Deemter L, et al: Multidrug-resistance protein 5 is a multispecific organic anion transporter able to transport nucleoside analogs. Pro Natl Acad Sci USA 97: 7476-7481, 2000.

24. Wielinga PR, Reid G, Challa EE et al: Thiopurine metabolism and identification of the thiopurine metabolites transported by MRP4 and MRP5 overexpressed in human embryonic kidney cells. Mol Pharmacol 62: 1321-1331, 2002. 
25. Reid G, Wielinga P, Zelcer N, et al: Characterization of the transport of nucleoside analog drugs by the human multidrug resistance proteins MRP4 and MRP5. Mol Pharmacol 63: 1094-1103, 2003.

26. Wang X, Furukawa T, Nitanda T, Okamoto M, Sugimoto $Y$, Akiyama S and Baba M: Breast cancer resistance protein (BCRP/ ABCG2) induces cellular resistance to HIV-1 nucleoside reverse transcriptase inhibitors. Mol Pharmacol 63: 65-72, 2003.

27. Chen ZS, Lee K, Walther S, Raftogianis RB, Kuwano M, Zeng H and Kruh GD: Analysis of methotrexate and folate transport by multidrug resistance protein 4 (ABCC4): MRP4 is a component of the methotrexate efflux system. Cancer Res 62: 3144-3150, 2002.

28. Peng XX, Shi Z, Damaraju VL, et al: Up-regulation of MRP4 and down-regulation of influx transporters in human leukemic cells with acquired resistance to 6-mercaptopurine. Leuk Res 32 799-809, 2008.

29. Kruh GD: Introduction to resistance to anticancer agents. Oncogene 22: 7262-7264, 2003.

30. Smith KM, Slugoski MD, Loewen SK, Ng AM, Yao SY, Chen XZ, et al: The broadly selective human $\mathrm{Na}^{+} /$nucleoside cotransporter (hCNT3) exhibits novel cation-coupled nucleoside transport characteristics. J Biol Chem 280: 25436-25499, 2005.

31. Fotoohi AK, Lindqvist $M$, Peterson $C$ and Albertioni $F$ : Involvement of the concentrative nucleoside transporter 3 and equilibrative nucleoside transporter 2 in the resistance of T-lymphoblastic cell lines to thiopurines. Biochem Biophys Res Commun 343: 208-215, 2006.

32. Breuninger LM, Paul S, Gaughan K, Miki T, Chan A, Aaronson SA and Kruh GD: Expression of multidrug associated protein in $\mathrm{NIH} / 3 \mathrm{~T} 3$ cells confers multidrug resistance associated with increased drug efflux and altered intracellular drug distribution. Cancer Res 55: 5342-5347, 1995.

33. Clarke ML, Damaraju VL, Zhang J, et al: The role of human nucleoside transporters in cellular uptake of 4'-thio-beta-Darabinofuranosylcytosine and beta-D-arabinosylcytosine. Mol Pharmacol 70: 303-310, 2006.

34. Cass CE, Young JD and Baldwin SA: Recent advances in the molecular biology of nucleoside transporters of mammalian cells, Biochem. Cell Biol 76: 761-770, 1998.

35. Chen ZS, Aoki S, Komatsu M, Ueda K, et al: Reversal of drug resistance mediated by multidrug resistance protein (MRP) 1 by dual effects of agosterol A on MRP1 function. Int J Cancer 93: $107-113,2001$
36. Chen ZS, Robey RW, Belinsky MG, et al: Transport of methotrexate, methotrexate polyglutamates, and 17beta-estradiol 17-(beta-D-glucuronide) by ABCG2: effects of acquired mutations at R482 on methotrexate transport. Cancer Res 63 4048-4054, 2003.

37. Peng XX and Li YB: Induction of cellular glutathione-linked enzymes and catalase by the unique chemoprotective agent, $3 \mathrm{H}$-1,2-dithiole-3-thione in rat cardiomyocytes affords protection against oxidative cell injury. Pharmacol Res 45: 491-497, 2002.

38. Bradford MM: A rapid and sensitive method for the quantitation of microgram quantities of protein utilizing the principle of protein-dye binding. Anal Biochem 72: 248-254, 1976.

39. Krynetskaia NF, Krynetski EY and Evans WE: Human RNase $\mathrm{H}$-mediated RNA cleavage from DNA-RNA duplexes is inhibited by 6-deoxythioguanosine incorporation into DNA. Mol Pharmacol 56: 841-848, 1999.

40. Mcleod HL, Relling MV, Liu Q, Pui CH and Evans WE: Polymorphic thiopurine methyltransferase in erythrocytes is indicative of activity in leukemic blasts from children with acute lymphoblastic leukemia. Blood 85: 1897-1902, 1995.

41. Hart SM, Ganeshaguru K, Hoffbrand AV, Prentice HG and Mehta AB: Expression of the multidrug resistance-associated protein (MRP) in acute leukemia. Leukemia 8: 2163-2168, 1994.

42. Wuchter $\mathrm{C}$, Leonid $\mathrm{K}$, Ruppert $\mathrm{V}$, et al: Clinical significance of P-glycoprotein expression and function for response to induction chemotherapy, relapse rate and overall survival in acute leukemia. Haematologica 85: 711-721, 2000.

43. Kuwazuru Y, Yoshimura A, Hanada S, et al: Expression of multidrug transporter, P-glycoprotein, in chronic myelogenous leukemia cells in blast crisis. Br J Haematol 74: 24-29, 1990.

44. Zeng H, Lin ZP and Sartorelli AC: Resistance to purine and pyrimidine nucleoside and nucleobase analogs by the human MDR1 transfected murine leukemia cell line L1210/VMDRC.06. Biochem Pharmacol 68: 911-921, 2004.

45. Loscher W and Potschka H: Blood-brain barrier active efflux transporters: ATP-binding cassette gene family. NeuroRx 2: 86-98, 2005

46. De Graaf D, Sharma RC, Mechetner EB, Schimke RT and Roninson IB: P-glycoprotein confers methotrexate resistance in 3T6 cells with deficient carrier mediated methotrexate uptake. Proc Natl Acad Sci USA 93: 1238-1242, 1996. 